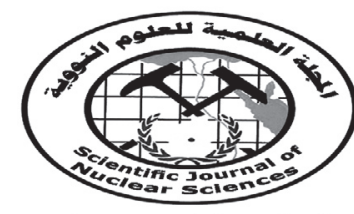

Nuclear Materials Authority P.o.Box 530 Maadi, Cairo, Egypt
ISSN 2314-5609

Nuclear Sciences Scientific Journal vol. $1, \mathrm{p}$ 85-97

2012

\title{
GEOLOGY OF WADI WASSIF AREA, CENTRAL EASTERN DESERT, EGYPT, WITH EMPHASIS ON MINERALOGY OF STREAM SEDIMENTS
}

\author{
ASHRAF E.I. SOLIMAN ,HESHAM A. EL NAHAS and ALI A. OMRAN \\ Nuclear Materials Authority. P.O. Box 530, El Maadi, Cairo, Egypt.
}

\begin{abstract}
This study deals with the geology and mineralogy of stream sediments at Wadi Wassif, C.E.D., Egypt. The area is built up of igneous and metamorphic rocks of Late Precambrian age in addition to Quaternary alluviam deposits. Geologically, the area consists of metavolcanics, older granitoids, Hammamat sediments, younger granites, and Quaternary sediments filling the streams of the studied area. Microscopically, metavolcanics comprise metaandesite, metadacite and crystal tuffs. They are weakly metamorphosed to the green schist facies (chlorite zone). Hammamat sediments comprise conglomerate, sandstone, siltstone and mudstone. They are weakly metamorphosed to the chlorite zone of the green schist facies. Gravity and magnetic separation techniques in addition to microscopic examination for the studied stream sediment samples were applied to evaluate the heavy minerals concentration of these sediments. The average heavy mineral concentration of the stream sediments of Wadi Wassif is 5.56\%, ranging from $1.58 \%$ and $10.91 \%$. These heavy minerals increase from upstream to downstream of Wadi Wassif. The average contents of the concerned heavy minerals in Wadi Wassif are $0.347 \%$ for zircon, $0.058 \%$ for thorite, $0.074 \%$ for monazite, 0.097 for titanite, $0.038 \%$ for rutile. The other heavy minerals include epidot, garnet in addition to opaque minerals; magnetite, ilmenite and hematite. The radiometric study of the stream sediments of Wadi Wassif indicates that the average concentrations of $U$ and $T h$ are $2.9 \mathrm{ppm}$ and $17 \mathrm{ppm}$ respectively, ranging from 1 to $4 \mathrm{ppm}$ for $\mathrm{U}$ and 8 to $28 \mathrm{ppm}$ for $\mathrm{Th}$, which reveals a significant fractionation during weathering of these sediments.
\end{abstract}

\section{INTRODUCTION}

Wadi Wassif area is located in the Central Eastern Desert of Egypt, and covering an area of about $48 \mathrm{Km}^{2}$. The area is delineated by Lat. $26^{\circ} 32^{\backslash}$ and $26^{\circ} 36 \mathrm{~N}$ and Long. $33^{\circ} 42^{\backslash}$ and $33^{\circ}$ $45^{`} \mathrm{E}$. , Fig 1 . It is entirely covered by igneous and metamorphic rocks that are dissected by several wadies e.g. Wadi Safaga, Wadi Wassif and Wadi Wateira. The area is studied by many authors, such as El Gaby, and Habib 1982, El Ramly, and El Akaad 1960 from different point of view.

The present work is concerned with geology of rock assemblages covering Wadi Wassif area, as well as heavy mineral concentrations in the stream sediments.

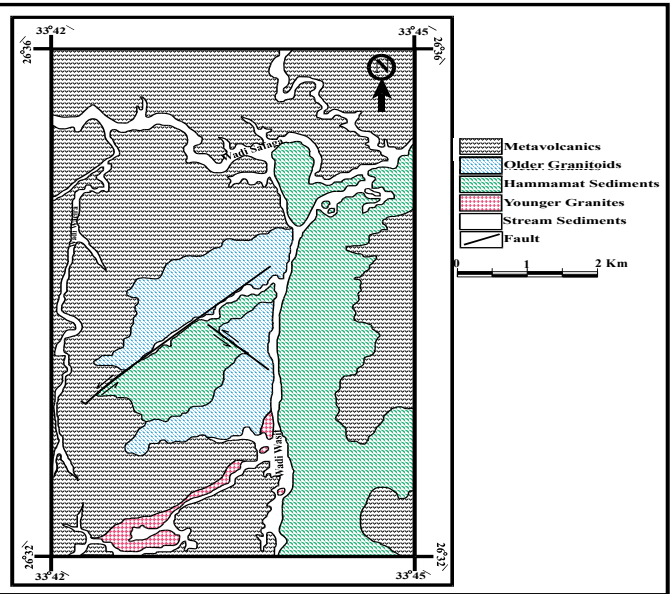

Fig. 1: Geologic map of Wadi Wassif Area 


\section{GEOLOGIC SETTING}

The rock assemblages cropping out at Wadi Wassif comprise, from the oldest to the youngest, metavolcanics, older granitoids, Hammamat sediments, younger granites and quaternary sediments filling the streams of the studied area. More than $50 \%$ of Wadi Wassif area is covered by metavolcanics that form irregular masses of high relief. They are characterized by dark green to yellowish green colour, highly foliated and jointed (Fig. 2). Sharp contacts between metavolcanics with both older granitoids and Hammamat sediments are present. Also, metavolcanics are intruded by younger granites in the southern part of Wadi Wassif. Stern (1981) divided the metavolcanics in the area between Latitudes $25^{\circ} 30^{\backslash}$ and $26^{\circ} 30^{`}$ in the Eastern Desert into older metavolcanics (OMV) and younger metavolcanis(YMV). The OMV are characterized by a thick mountainous succession of pillowed metabasalts, and rare sedimentary interbeds. They are associated with metagabbros and serpentinites of ophiolitic nature.

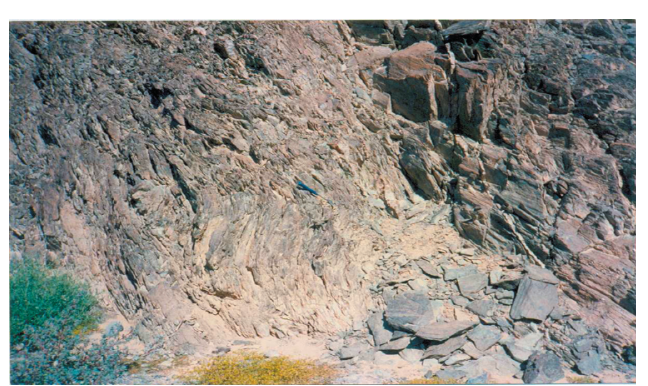

Fig. 2: Highly foliated, faulted and jointed metavolcanics of Wadi Wassif area

The YMV occur as andesitic sequence that overlie and interfinger with immature sediments. In Wadi Wassif area YMV can be distinguished from OMV by the abundance of porpheritic and more felsic lithologies, the abundance of volcaniclastic sediments, and the scarcity of large pillows, as well as the absence of associated serpentinites.
Older granitoids crop out to the west of Wadi Wassif. They form large masses of moderate relief extending as elongated belt in the NE-SW direction and forming fault contact represented by right lateral strike-slip fault with Hammamat sediments. These rocks contain xenoliths of metavolcanics. Older granitoids are coarse grained, highly sheared and jointed, and characterized by cavernous structure, well developed exfoliation (Fig. 3) and show gneissose structure especially along and near their contacts and peripheries. They show heterogeneous nature, tonalite in composition, and related to the synorogenic calc-alkaline granites of El Gaby and Habib, 1982.

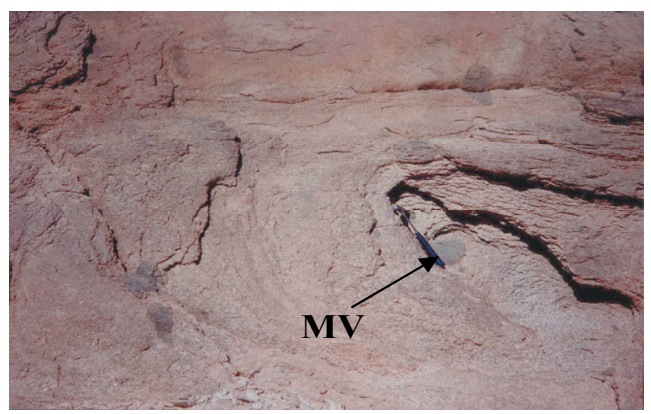

Fig. 3: Older granitoids show carnivorous structure, well developed exfoliation and containing xenoliths of metavolcanics (MV)

Hammamat sediments are well exposed in Wadi Wassif, where they occur as elongated strip trending N-S and forming the eastern shoulder of Wadi Wassif. Also, they crop out to the west of Wadi Wassif at the central part. They locally show cyclothems, where conglomerate bands occur at the base followed upward by greywacke and siltstones at the upper part of the succession in addition to slaty foliation nature (Fig. 4). They possess primary and diagenetic sedimentary structures including laminations, normal graded bedding and convolute bedding.

The studied younger granites form the highest mountainous bodies in the area, and located 


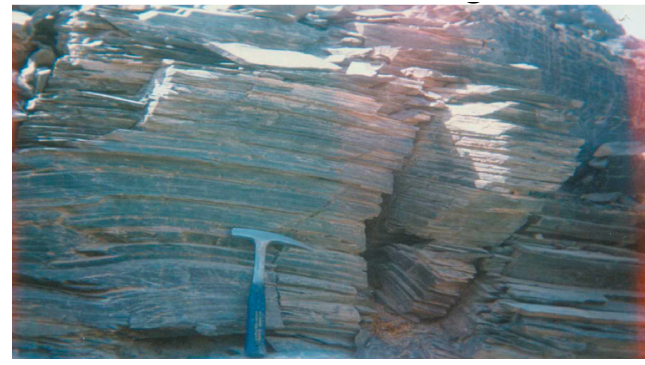

Fig. 4: Foliation in Hammamat sediments

in the southwestern part of Wadi Wassif. They intrude metavolcanics with sharp contacts. These granites belong to gattarian granites (El Ramly and Akaad, 1960). They were emplaced during the post tectonic episode in Egypt, contempaneous with the Pan African tectono-thermal events.

The rock assemblages of Wadi Wassif area are dissected by several wadies. The main wadies in the studied area are Wadi Safaga in the north, Wadi Wassif, and Wadi Wateira in the west. The directions of these wadies are coincident with the large scale faults and covered mainly by stream sediments. It is apparent that the N-S, NE-SW, NW-SE and E-W trends are the significant major faults controlling the wide wadies in the studied area. The stream sediments of Wadi Wassif are composed mainly of loose sand with gravel, pebbles and rarely cobbles, which imbedded in sandy matrix.

\section{MICROSCOPIC EXAMINATION}

The metavolcanics comprise meta-andesite, metadacite and crystal tuffs. They are weakly metamorphosed to green schist facies (chlorite zone). Meta-andesite rocks are altered, porphyroblasts and amygdaloidal. Subhedral plagioclase phenocrysts show preferred orientation (Fig. 5a) and measuring up to $1.3 \mathrm{~mm}$ in length. They are mostly altered to a mixture of calcite, ziosite and chlorite. Few fresh crystals are determined to be andesine $\left(\mathrm{An}_{43-47}\right)$ in composition. These phenocrysts, together with large patches of chlorite after some ferromagnesian minerals, are embedded in a groundmass of small, subparallel plagioclase laths, abundant opaques, quartz, as well as numerous amygdales. The latter are irregular in shape, measuring up to $1.2 \mathrm{~mm}$, and are filled mainly with calcite and chlorite. Metada- cites are greenish-grey in colour, altered and porphyroblastic. Subhedral plagioclase phenocrysts are saussoritized and measured up to $1.2 \mathrm{~mm}$ in length. They have a sodic labradorite $\left(\mathrm{An}_{55-57}\right)$ composition. Quartz phenocrysts are embedded and corroded along fractures (Fig. 5b). They measure up to $1.7 \mathrm{~mm}$. The phenocrysts are embedded in a fine-grained groundmass consisting of small plagioclase laths, quartz, chlorite and opaques. Crystal tuffs are composed essentially of andesine $\left(\mathrm{An}_{34-40}\right)$ and quartz often corroded by the groundmass. Some of these tuffs are banded by the variation in the grain size (Fig. 5c). Iron oxides pepper the groundmass in specks and granules, and form trails. The rocks are affected by polyphase of deformation. They display foliation that is defined by preferred orientation of elongated quartz, muscovite flakes and mainly trails of iron oxide crystals.

Older granitoids are medium to coarsegrained, and grey in colour. They are com-

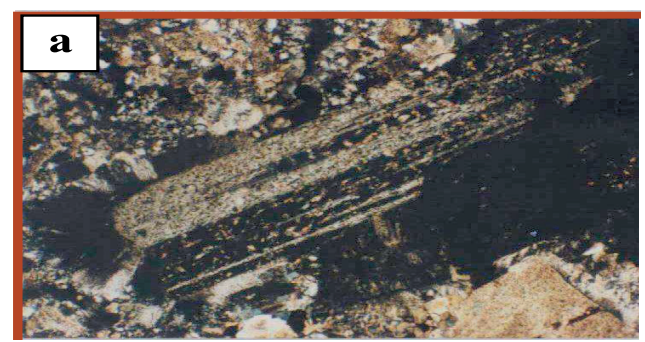

Fig.5.a: Altered and oriented plagioclase phenocrysts in a groundmass of subparallel plagioclase laths, abundant opaque and minor quartz, meta-andesite. C. N. x 4

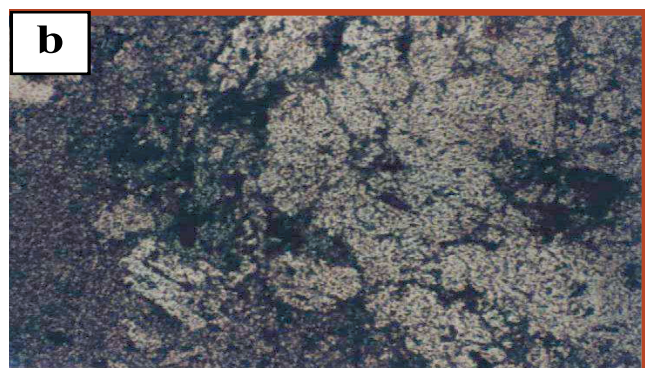

Fig.5.b: Fractured and corroded phenocrysts of quartz in a fine-grained chlorite-rich groundmass, Porphyroblastic metadacite. C. N. x 4. c) Banded tuff exhibiting variation in grain size and modal proportions of the main constituents; quartz, chlorite and iron oxides. C. N. x 4. 


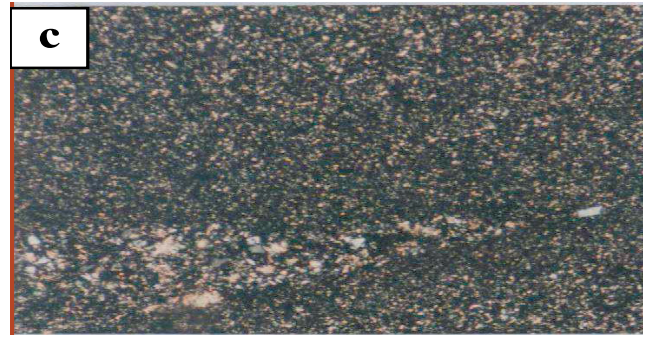

Fig.5.c: Banded tuff exhibiting variation in grain size and modal proportions of the main constituents; quartz, chlorite and iron oxides. C. N. x 4

posed essentially of oligoclase, quartz, orthoclase, hornblende and muscovite (Fig. 5d). Opaques and zircon are the common accessories. The common secondary constituents include serisite, epidot and chlorite. Plagioclase $\left(\mathrm{An}_{22-25}\right)$ occurs as subhedral, tabular crystals, displaying zoning and varying degrees of saussoritization often restricted to the core of the crystal (Fig. 5e). Quartz commonly forms anhedral to subhedral and crystal aggregates, and shows highly corrosive outlines against plagioclase, potash feldspar and hornblende. Hornblende occurs as pale brown subhedral crystals, frequently altered to actinolite with release of iron oxide along cleavage traces, and enclosing numerous anhedral iron oxide crystals. Potash feldspars are commonly represented by cloudy orthoclase twinned according to the Carlsbad Low, and by small interstitial crystals of microcline exhibiting characteristic cross-hatching twinning.

Hammamat sediments comprise conglomerates, sandstones, siltstones and mudstones

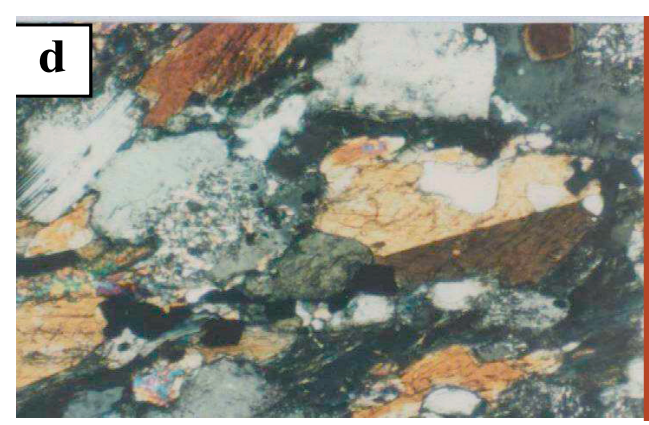

Fig.5.d: Deformation and partially obliterated lamellar twinning in altered plagioclase, and weak preferred orientation of hornblende. Older granitoids. C. N. x 4

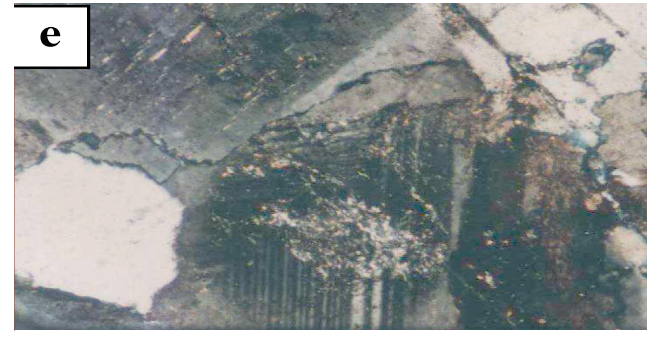

Fig.5.e: Zoned plagioclase crystal showing saussoritization restricted to the core. Older granitoids. C.N.x10

that are weakly metamorphosed to the chlorite zone of the greenschist facies. Evidence of deformation is best seen microscopically in sandstones, siltstones and mudstones. Conglomerates are mainly composed of large $(>4 \mathrm{~mm}$.) angular to subangular quartz, plagioclase crystal fragments and lithic fragments. Sandstones are grain-supported and angular to subangular minerals and lithic fragments that are embedded in a matrix of serisite, chlorite, epidot and sphene. Plagioclase fragments are abundant and display serisitization, kinking and bent twinning. Abundant quartz exhibits wavy extinction and incipient crystallization. Cloudy orthoclase and bent chlorite flakes are subordinate. The green siltstones are composed of angular to subangular clastic grains of quartz, cloudy orthoclase and tiny scales of serisite and chlorite.

The clastic grains are embedded in an iron oxide-rich clayey matrix, which may be partly replaced by carbonates. These rocks are mostly matrix-supported. They display well developed slaty cleavage, microfolding and microfaulted bedding (Figs. $5 \mathrm{f} \& \mathrm{~g}$ ). The mudstones are greenish laminated rocks composed of small quartz clasts, with minor plagioclase and muscovite flakes embedded in a finegrained clayey and chloritic matrix. The clasts / matrix ratio illustrates that these rocks are grained-supported with interstitial matrix.

Younger granites are holocrystalline, medium to coarse-grained exhibiting light pink colour and show hypidiomorphic granular texture (Fig. 5h). They are composed mainly 


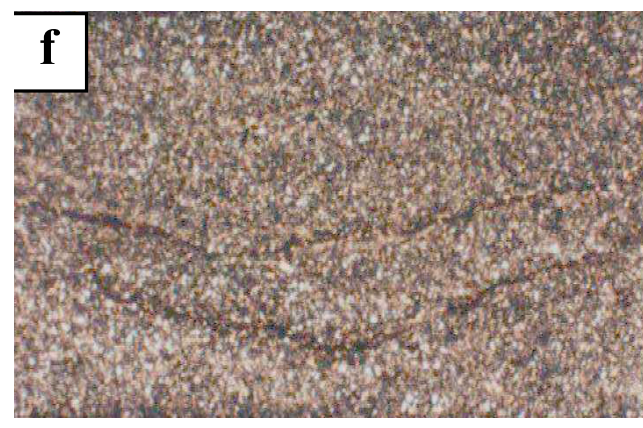

Fig.5.f: Open F3 fold in green siltstone-mudstone. C. N. $x 4$

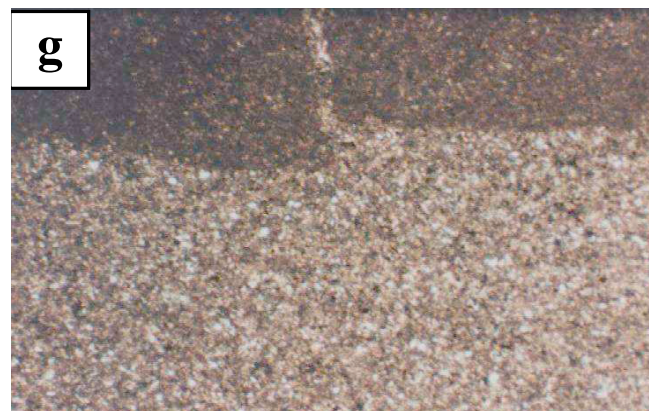

Fig.5.g: Microfaulted bedding and variation in modal proportions of clastic quartz, and size grading of fragments in Siltstone-mudstone. C. N. x 4

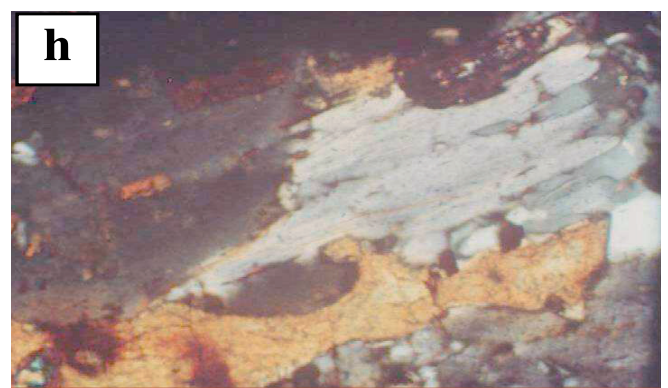

Fig.5.h: Subhedral to anhedral crystals up to $2.3 \times 4$ $\mathrm{mm}$ and rarely as euhedral crystals of the essential minerals of younger granites, slightly affected with alteration processes.C.N. $\mathrm{x} 4$

of microcline, plagioclase, quartz, biotite and muscovite. The accessory minerals include zircon, sphene, apatite and opques. Chlorite, epidot, serisite and koalinite are the main secondary minerals. Opaque minerals occur as anhedral to subhedral, occasionally as euhedral, grains scattered through the rocks and often engulfed within biotite and quartz. Zircon occurs as interstitial zoned tabular crystals, or as inclusions in biotite, plagioclase and quartz. Sphene is very rare exhibiting spheniodal shape within other minerals. Apatite occurs as minute euhedral tabular and needle-like crystals associated with the other constituents and occasionally enclosed within them.

\section{EVALUATION OF STREAM SEDIMENTS}

\section{Sampling and Techniques}

A total of eleven stream sediment samples were collected from Wadi Wassif through spot samples to the depth of about $70 \mathrm{~cm}$. the samples spacing were $500 \mathrm{~m}$ apart. These samples were prepared for quantitative mineralogical analyses. The samples were air-dried, quartered using both John's Splitter and an automatic rotary Splitter to obtain representative samples for different mineralogical treatments.

Quantitative mineralogical analyses for the stream sediment were carried out by gravity separation using a Wilfley Shaking Table (No. 13), heavy liquid separation using bromoform solution (Sp. Gr. $2.81 \mathrm{~g} / \mathrm{cm}^{3}$ ), magnetic fractionation using a Frantz Isodynamic Magnetic Separator (Model L-1) and a Binocular Stereomicroscope.

Mineralogical investigation of the mineral constituents of the stream sediments of Wadi Wassif was carried out by X-ray diffraction technique. A Phillips X-ray diffractometer (Model PW-1010) with a scintillation counter (Model PW-25623/00) and Ni filter was used. Semiquantitative EDX chemical analyses were carried out using a Phillips XL-30 Environmental Scanning Electron Microscope (ESEM).

Determinations of the eU, eTh and $\mathrm{Ra}$ (ppm) and $\mathrm{K}(\%)$ concentrations of the studied stream sediments were carried out using a Bicron Scintillation Detector NaI (TI) $76 \times 76 \mathrm{~mm}$. The samples were crushed to pass 
through $0.5 \mathrm{~mm}$ sieve to homogenize them. They were packed in plastic containers, sealed carefully, and stored for more than thirty days prior to counting.

\section{Heavy Minerals Distribution}

To obtain the heavy minerals from the studied stream sediment and remove the gangue minerals, especially quartz and feldspars which constitute more than $85 \%$ of the stream sediments of Wadi Wassif, the gravity separation technique was applied using a Wilfley Shaking Table (No. 13). The fractions resulted from the wet-tabling of the studied samples were a table concentrate containing most of the heavy minerals, and a tailing fraction composed mainly of quartz and feldspars. Because of the table concentrates were still contain some of gangue minerals, up to about $10 \%$, they were subjected to the heavy liquid separation using the bromoform solution (Sp.gr. $2.81 \mathrm{~g} / \mathrm{cm}^{3}$ ). The average content of the heavy minerals in the studied stream sediments is $5.56 \%$ ranging from $1.58 \%$ and $10.91 \%$ (Table 1 ). The content of the heavy minerals in the studied stream sediments increases from south (upstream) to north (downstream).

Magnetic separation using a hand magnet and Frantz Isodynamic Magnetic Separator (model L-1) were used to fractionate heavy minerals according to their magnetic susceptibilities. First, magnetite was collected by

Table 1: The percentages of the heavy minerals in the studied stream sediments of Wadi Wassif

\begin{tabular}{|c|c|}
\hline Sample No & Heavy minerals \% \\
\hline WS1 & 1.5815 \\
\hline WS2 & 1.9862 \\
\hline WS3 & 2.6525 \\
\hline WS4 & 3.0582 \\
\hline WS5 & 6.0099 \\
\hline WS6 & 6.3312 \\
\hline WS7 & 5.1551 \\
\hline WS9 & 7.4291 \\
\hline WS10 & 10.9101 \\
\hline WS11 & 8.1512 \\
\hline Average & $\mathbf{5 . 5 4 2 3}$ \\
\hline Min. & $\mathbf{1 . 5 8 1 5}$ \\
\hline Max. & $\mathbf{1 0 . 9 1 0 1}$ \\
\hline
\end{tabular}

a hand magnet, and then the free-magnetite samples were subjected to the magnetic separation at $0.2,0.5,1.0$ and 1.5 current amperes. The obtained fractions were weighed and their percentages were calculated (Table 2). It is obviously noted that the heavy minerals are concentrated mainly in $0.2 \mathrm{amp}$ and $0.5 \mathrm{amp}$ magnetic fractions; while $1.5 \mathrm{amp}$ magnetic fraction contains the lowest concentration of the heavy minerals.

Table 2: Frequency of the heavy minerals in the different magnetic fractions

\begin{tabular}{|c|c|c|c|c|c|c|}
\hline & $\begin{array}{c}\text { Magnetite } \\
\mathbf{\%}\end{array}$ & $\begin{array}{c}\mathbf{0 . 2 m a g .} \\
\mathbf{\%}\end{array}$ & $\begin{array}{c}\mathbf{0 . 5 m a g .} \\
\mathbf{\%}\end{array}$ & $\begin{array}{c}\mathbf{1 . 0 m a g .} \\
\mathbf{.} \%\end{array}$ & $\begin{array}{c}\mathbf{1 . 5 m a g .} \\
\mathbf{\%}\end{array}$ & $\begin{array}{c}\mathbf{1 . 5 N o n m a} \\
\mathbf{g} . \%\end{array}$ \\
\hline WS1 & 15.592 & 33.817 & 43.608 & 3.230 & 1.722 & 2.031 \\
\hline WS2 & 35.953 & 24.644 & 36.661 & 1.332 & 0.113 & 1.296 \\
\hline WS3 & 13.198 & 58.717 & 23.476 & 2.378 & 0.772 & 1.460 \\
\hline WS4 & 30.745 & 42.063 & 11.542 & 4.000 & 2.143 & 9.507 \\
\hline WS5 & 14.174 & 40.342 & 40.320 & 2.353 & 0.219 & 2.593 \\
\hline WS6 & 25.338 & 39.717 & 26.474 & 1.925 & 1.035 & 5.510 \\
\hline WS7 & 18.003 & 36.867 & 37.651 & 2.868 & 0.302 & 4.309 \\
\hline WS8 & 28.680 & 33.843 & 35.191 & 0.590 & 0.220 & 1.476 \\
\hline WS9 & 16.005 & 24.103 & 38.478 & 4.432 & 4.151 & 12.830 \\
\hline WS10 & 19.354 & 34.278 & 44.762 & 0.973 & 0.125 & 0.507 \\
\hline WS11 & 20.541 & 61.871 & 16.552 & 0.577 & 0.000 & 0.460 \\
\hline
\end{tabular}

Each fraction obtained from the magnetic separation process was microscopically investigated to calculate the frequency distribution of the concerned minerals in the studied stream sediment. A considerable number of grains from each magnetic fraction were counted (about 1500 grains). The weight percentage of each concerned mineral relative to the corresponding original sample was calculated according to Stakhove equation (1957):

$$
\mathrm{Q}=\left[\mathrm{P} . \mathrm{n}_{\mathrm{m}} \cdot \mathrm{d}_{\mathrm{m}} / \Sigma\left(\mathrm{n}_{\mathrm{o}} \mathrm{d}_{\mathrm{o}}\right)\right] \cdot 100
$$

Where: $\mathrm{Q}=$ the weight percentages of the concerned mineral

$\mathrm{P}=$ the weight percentage of the corresponding magnetic fraction.

$\mathrm{n}_{\mathrm{m}}=$ the number of grains of the mineral.

$\mathrm{d}_{\mathrm{m}}=$ specific gravity of the mineral.

$\Sigma\left(\mathrm{n}_{\mathrm{o}} \mathrm{d}_{\mathrm{o}}\right)=$ the sum of the number of grains for each mineral multiplied by its specific gravity. 
The common heavy minerals in the studied stream sediments are thorite, zircon, titanite, monazite, garnet, rutile, epidot in addition to opaque minerals magnetite, ilmenite and hematite (Table 3).

Table 3: The weight percentages of the concerned heavy minerals in the studied stream sediment samples

\begin{tabular}{|c|c|c|c|c|c|c|c|c|c|c|c|}
\hline & Thrt & Tita. & Zr & Monz & Garnt & Hm & Rut & Epi & Ilm & Mag & $\begin{array}{c}\text { Am } \\
\text { \& P }\end{array}$ \\
\hline WS1 & 0.026 & 0.103 & 0.065 & 0.032 & 0.110 & 0.072 & 0.003 & 0.015 & 0.103 & 0.247 & 0.806 \\
\hline WS2 & 0.025 & 0.098 & 0.062 & 0.031 & 0.105 & 0.068 & 0.003 & 0.015 & 0.098 & 0.714 & 0.768 \\
\hline WS3 & 0.086 & 0.084 & 0.041 & 0.023 & 0.062 & 0.101 & 0.003 & 0.042 & 0.083 & 0.350 & 1.779 \\
\hline WS4 & 0.079 & 0.077 & 0.037 & 0.021 & 0.057 & 0.093 & 0.002 & 0.039 & 0.076 & 0.940 & 1.636 \\
\hline WS5 & 0.024 & 0.053 & 0.135 & 0.078 & 0.213 & 0.126 & 0.008 & 0.120 & 0.071 & 0.852 & 4.113 \\
\hline WS6 & 0.043 & 0.048 & 0.124 & 0.071 & 0.196 & 0.116 & 0.008 & 0.110 & 0.065 & 1.604 & 3.769 \\
\hline WS7 & 0.121 & 0.060 & 0.179 & 0.089 & 0.376 & 0.023 & 0.011 & 0.763 & 0.105 & 0.928 & 2.499 \\
\hline WS8 & 0.082 & 0.075 & 0.225 & 0.111 & 0.471 & 0.029 & 0.014 & 0.957 & 0.132 & 2.131 & 3.133 \\
\hline WS9 & 0.065 & 0.191 & 1.247 & 0.141 & 0.763 & 0.047 & 0.152 & 1.721 & 0.081 & 1.746 & 4.476 \\
\hline WS10 & 0.057 & 0.137 & 0.894 & 0.101 & 0.548 & 0.034 & 0.109 & 1.235 & 0.058 & 1.578 & 3.210 \\
\hline WS11 & 0.032 & 0.137 & 0.812 & 0.122 & 0.554 & 0.048 & 0.106 & 1.174 & 0.074 & 1.611 & 3.002 \\
\hline Min & 0.024 & 0.048 & 0.037 & 0.021 & 0.057 & 0.023 & 0.002 & 0.015 & 0.058 & 0.247 & 0.768 \\
\hline Max & 0.121 & 0.191 & 1.247 & 0.141 & 0.763 & 0.126 & 0.152 & 1.721 & 0.132 & 2.131 & 4.476 \\
\hline Av. & $\mathbf{0 . 0 5 8}$ & $\mathbf{0 . 0 9 7}$ & 0.347 & $\mathbf{0 . 0 7 4}$ & $\mathbf{0 . 3 1 4}$ & $\mathbf{0 . 0 6 9}$ & $\mathbf{0 . 0 3 8}$ & 0.5563 & $\mathbf{0 . 0 8 6}$ & $\mathbf{1 . 1 5 5}$ & $\mathbf{2 . 6 5 4}$ \\
\hline
\end{tabular}

Thorite [ThSiO ]: occurs widely in the form of accessory minerals, which belongs to the most important basic commercial minerals of thorium. Thorite constitutes $0.058 \%$ of the studied stream sediments. It occurs as brownish black to black opaque grains of greasy luster (Fig. 6a). Most of thorite mineral grains are subhedral to anhedral corroded and cracked. Rarely, euhedral prismatic thorite grains are present. They are strongly metamictized, as determined by X-ray diffraction. In nature, thorite, generally, occurs in metamict state, amorphous to X-ray and electron diffraction, even though, they may have crystal faces (Palache et al. 1944, Pabst 1952, Ewing and Haaker 1980). Thorite was annealed at $1100^{\circ} \mathrm{C}$ for approximately four hours preceding identification by XRD. The obtained data (Table 4) reveal the presence of thorite peaks (ASTM card 11-419) in addition to hematite peaks (ASTM card 13-534). The presence of hematite may be in the form of thin films coating thorite grains or as individual hematite grains. The ESEM analysis shows that thorite consists mainly of $\mathrm{ThO}_{2}$ and $\mathrm{SiO}_{2}$. Minor and trace elements include $\mathrm{Y}, \mathrm{U}, \mathrm{Ca}, \mathrm{Fe}$ and $\mathrm{REE}$ (Fig. 6b).

Zircon [ $\mathrm{ZrSiO} /]$ is a remarkable mineral due to its ubiquitous occurrence in crustal igne-

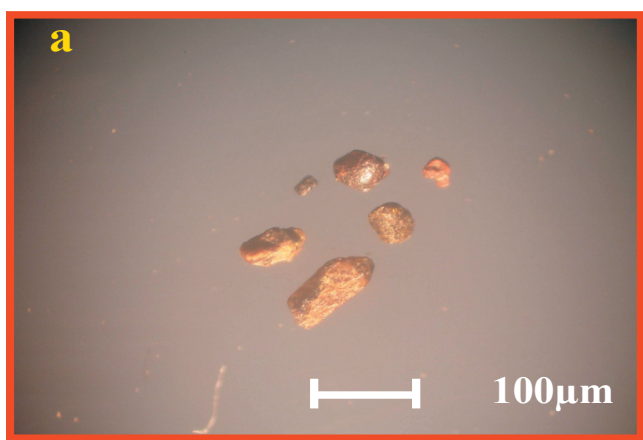

Fig. 6a: Photomicrographs showing mineral grains of thorite

Table 4: X-ray diffraction data of the annealed thorite from the studied stream sediments

\begin{tabular}{|c|c|c|c|c|c|}
\hline \multicolumn{2}{c|}{$\begin{array}{c}\text { Analyzed } \\
\text { Sample }\end{array}$} & \multicolumn{2}{c|}{$\begin{array}{c}\text { Thorite } \\
\text { ASTM card (11-419) }\end{array}$} & \multicolumn{2}{c|}{$\begin{array}{c}\text { Hematite } \\
\text { ASTM card (13-534) }\end{array}$} \\
\hline dA & I/Io & dA & $\mathbf{I} / \mathbf{I}$ & dA & I/Io \\
\hline 4.67 & 59 & 4.72 & 85 & & \\
\hline 3.54 & 100 & 3.55 & 100 & 3.66 & 25 \\
\hline 2.82 & 21 & 2.842 & 45 & & \\
\hline 2.70 & 32 & & & 2.69 & 100 \\
\hline 2.64 & 46 & 2.676 & 75 & & \\
\hline 2.52 & 21 & 2.516 & 30 & 2.51 & 50 \\
\hline 2.34 & 3 & 2.361 & 5 & & \\
\hline 2.20 & 22 & 2.222 & 30 & 2.201 & 30 \\
\hline 2.07 & 2 & & & 2.07 & 2 \\
\hline 1.99 & 9 & 2.019 & 20 & & \\
\hline 1.87 & 15 & 1.885 & 30 & & \\
\hline 1.82 & 28 & 1.834 & 65 & 1.838 & 40 \\
\hline 1.77 & 10 & 1.782 & 20 & & \\
\hline 1.69 & 12 & & & 1.69 & 60 \\
\hline 1.65 & 8 & 1.667 & 10 & 1.634 & 4 \\
\hline 1.48 & 5 & 1.484 & 20 & 1.484 & 35 \\
\hline 1.43 & 4 & 1.444 & 15 & 1.453 & 35 \\
\hline
\end{tabular}

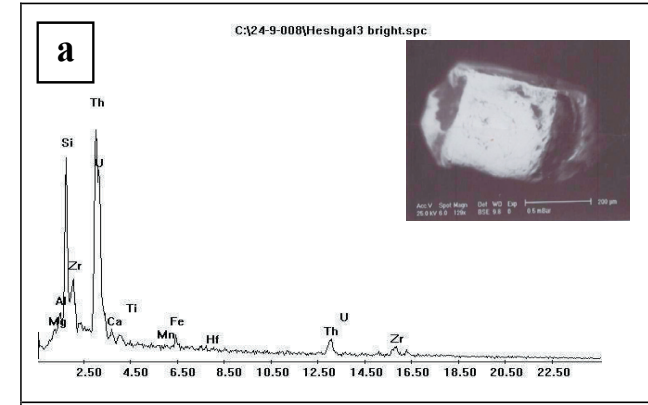

Fig. 6b: ESEM analyses for the studied heavy minerals from Wadi Wassif; thorite 
ous, metamorphic and sedimentary rocks, and in even mantle xenoliths, lunar rocks, meteorites and tektite (Speer 1980). Zircon constitutes $0.347 \%$ of the studied stream sediments. It occurs as subhedral to anhedral grains exhibiting colourless to brownish yellow colours of adamantine luster. Prismatic, barrel, needle and broken crystals are the prominent forms of zircon (Fig. 6c), while few zircon grains are well preserved as euhedral crystals with bipyramidal termination. ESEM data indicate that zircon consists mainly of $\mathrm{ZrO}_{2}$ and $\mathrm{SiO}_{2}$ with trace amounts of $\mathrm{Ca}, \mathrm{Hf}, \mathrm{Fe}$ and $\mathrm{Al}$ (Fig. 6d). The $\mathrm{Zr} / \mathrm{Hf}$ ratio is a principle indicator of magmatic differentiation. The average $\mathrm{Zr} / \mathrm{Hf}$ of zircon from granitoid rocks is 37.3 , while this ratio reaches to 49.6 for volcanic rocks, 55.7 for basic rocks and 67 for ultrabasic rocks (Lyakhvich and Vishneveskiy 1990). For the studied zircon, $\mathrm{Zr} / \mathrm{Hf}$ ranges from 31.15 to 56.78 , indicating that they may be derived from granitic, basic and metamorphic rocks.

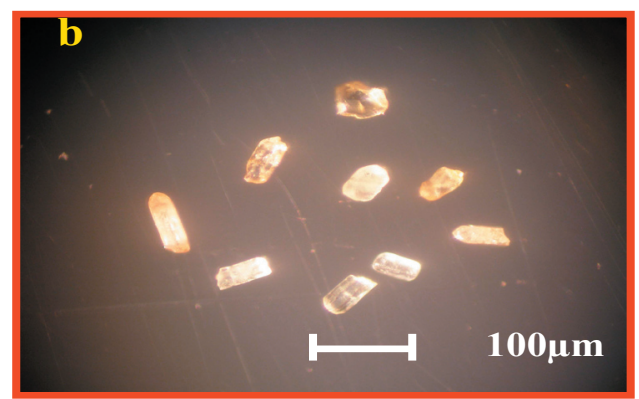

Fig. 6c: Photomicrographs showing mineral grains of b) zircon

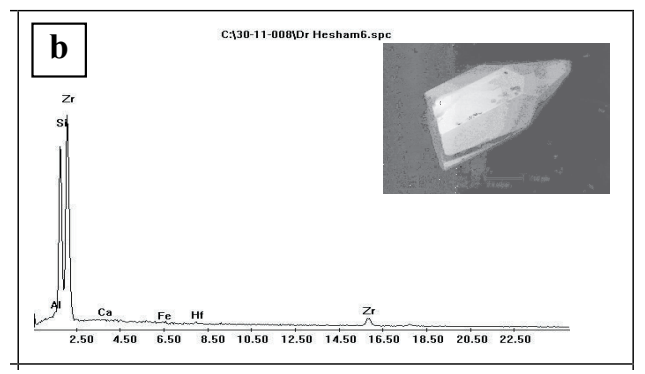

Fig. 6d: ESEM analyses for the studied heavy minerals from Wadi Wassif; b) zircon
Titanite [CaTiSiO 5 ]: is widespread in acidic, intermediate igneous rocks, and in several metamorphic rocks as accessory phase. Titanite constitutes $0.097 \%$ of the studied stream sediments. It exhibits transparent to translucent yellow to yellowish brown colours (Fig. 6e). Titanite mineral grains are subhedral to anhedral grains of adamantine luster and imperfect cleavage. The presence of titanite in the studied sediments was identified by ESEM and confirmed by X-ray diffraction (Table 5).

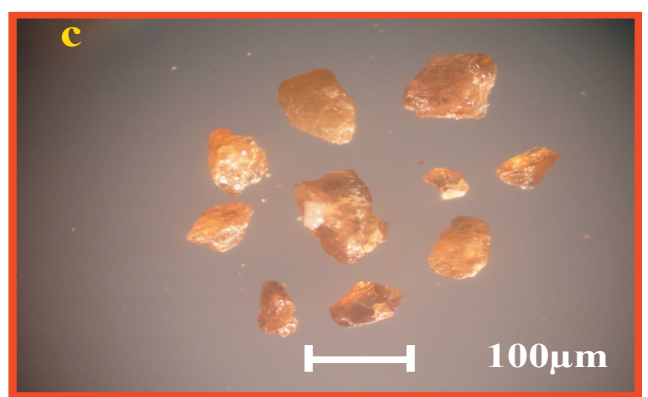

Fig. 6e: Photomicrographs showing mineral grains of titanite

Table 5: X-ray diffraction data of titanite of Wadi Wassif area

\begin{tabular}{|c|c|c|c|}
\hline \multicolumn{2}{|c|}{ Analysed Sample } & \multicolumn{2}{c|}{$\begin{array}{c}\text { Titanite } \\
\text { ASTM card (11-446) }\end{array}$} \\
\hline dA & $\mathbf{I}_{\mathbf{0}}$ & $\mathbf{d A}$ & $\mathbf{I}_{\mathbf{0}}$ \\
\hline 7.22 & 6 & & \\
\hline 4.95 & 23 & 4.93 & 30 \\
\hline 3.24 & 100 & 3.233 & 100 \\
\hline 3.00 & 97 & 2.989 & 90 \\
\hline 2.61 & 67 & & \\
\hline 2.59 & 55 & 2.595 & 90 \\
\hline 2.29 & 19 & 2.273 & 30 \\
\hline 2.07 & 27 & 2.058 & 40 \\
\hline 1.65 & 24 & 1.643 & 40 \\
\hline 1.50 & 17 & 1.494 & 4 \\
\hline
\end{tabular}

The EDX of most titanite grains reveal the presence of minor amounts of $\mathrm{Al}, \mathrm{Fe}, \mathrm{U}$ and Th (Fig. 6f). Isomorphous for $\mathrm{Ca}$ are $\mathrm{Na}$, $\mathrm{REE}$ and minor Th and $\mathrm{U}$; isomorphous for $\mathrm{Ti}$ are $\mathrm{Fe}, \mathrm{Al}$, and $\mathrm{Nb}$. Traces of $\mathrm{Zr}, \mathrm{Pb}, \mathrm{Sn}, \mathrm{V}, \mathrm{C}$, $\mathrm{Ga}$, Ta and $\mathrm{Ba}$ have been detected (Heinrich 1958). Inclusions of zircon and ilmenite were detected in titanite (Fig. 6g). 


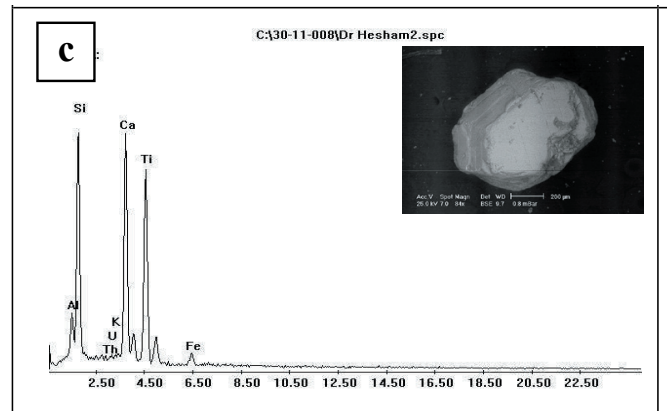

Fig. 6f: ESEM analyses for the studied heavy minerals from Wadi Wassif; c) titanite

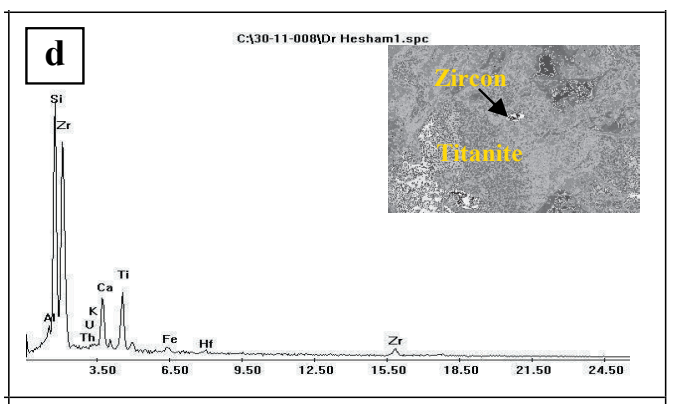

Fig. 6g: ESEM analyses for the studied heavy minerals from Wadi Wassif; d) inclusion of zircon within titanite

Monazite [CePO]: is one of the most important nuclear minerals, being a major host for REEs and actinides Th and U (Hinton and Paterson 1994, Bea et al. 1994, Bea 1996). Monazite in the studied samples is rare constituting $0.074 \%$ of the heavy minerals of these samples. It forms rounded to well rounded pale yellow, honey yellow, greenish yellow and reddish yellow grains (Fig. 6h). The absorption spectrum of monazite is determined mainly by $\mathrm{Nd}$ and $\mathrm{Pr}$ elements, $\mathrm{Fe}^{3+}, \mathrm{Fe}^{2+}$ oxides content are the reason of coloration (Karavtchenko 1960). The tabular and broken crystals are frequent. Most of these grains are characterized by pitted surfaces. The EDX data (Fig. 6i) shows that $\mathrm{Ce}$ is the dominant A-site cation, and so monazite can be referred as monazite-(Ce). Also, the average $\mathrm{Th}$ and $\mathrm{U}$ contents in these monazites are $6.84 \%$ and $2.76 \%$ respectively.

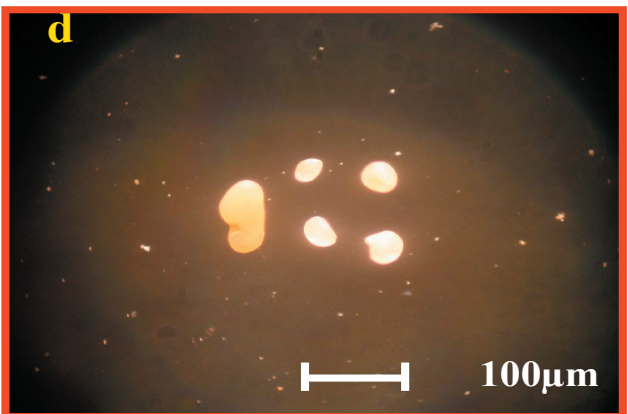

Fig. 6h: Photomicrographs showing mineral grains of titanite, d) monazite

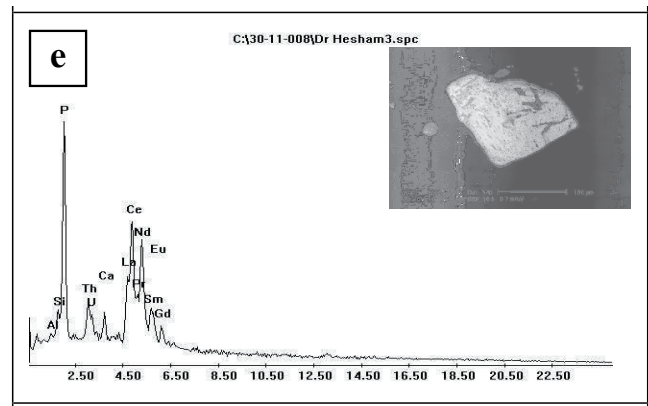

Fig. 6i: ESEM analyses for the studied heavy minerals from Wadi Wassif; e) monazite

Rutile [TiO $]$ : is the preferred mineral for the production of titanium dioxide. Rutile constitutes $0.038 \%$ of the heavy minerals of studied stream sediments. Rutile mineral grains are commonly prismatic, elongated, tabular and massive granular in shape (Fig. 6j). The common colors of rutile are reddish brown grading into the red and black with adamantine luster. The EDX shows the chemical composition of rutile, where minor amounts of $\mathrm{Si}, \mathrm{Ca}, \mathrm{Fe}, \mathrm{Mg}$ and $\mathrm{Al}$ are present (Fig. 6k).

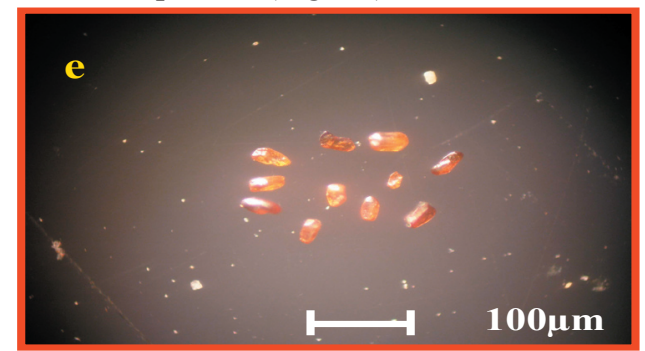

Fig. 6j: Photomicrographs showing mineral grains of e) rutile and f) pyrite 


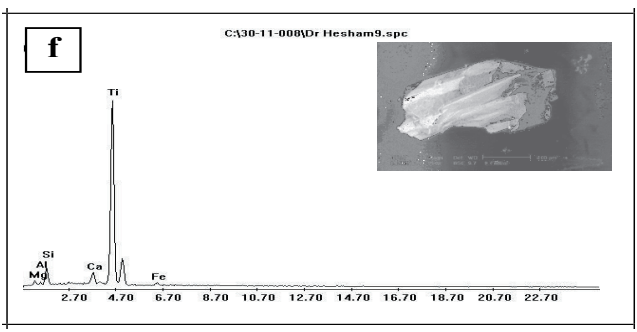

Fig. 6k: ESEM analyses for the studied heavy minerals from Wadi Wassif; f) rutile

Pyrite [FeS]: is by far the most widespread and commonly occurring sulfide mineral. It can be found in almost any type of geologic environment (Berry et al. 1983). Pyrite is very rare in the studied stream sediments. It occurs as massive, granular or rounded grains of brownish black to greenish black colors (Fig. 61). Some pyrite grains change to iron oxide retaining the same form of pyrite (Fig. $6 \mathrm{~m}, \mathrm{n}$ ). Wenk and Bulakh (2004) pointed out that during oxidation; iron hydroxide called limonite replaces pyrite.

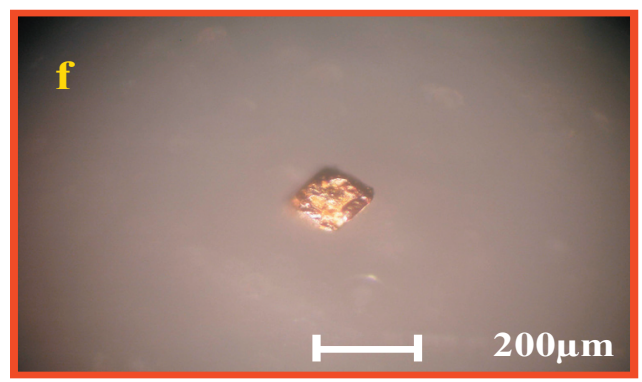

Fig. 61: Photomicrographs showing mineral grains of $f$ ) pyrite

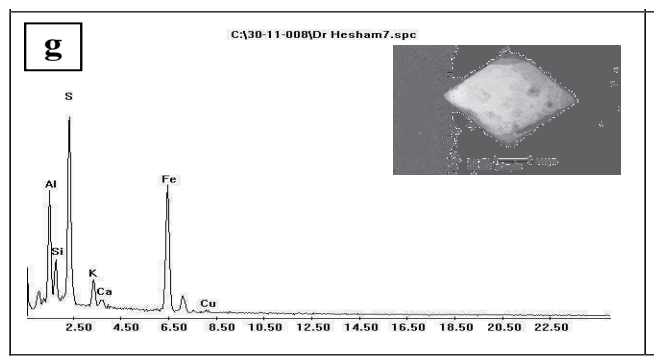

Fig. 6m: ESEM analyses for the studied heavy minerals from Wadi Wassif; g) pyrite

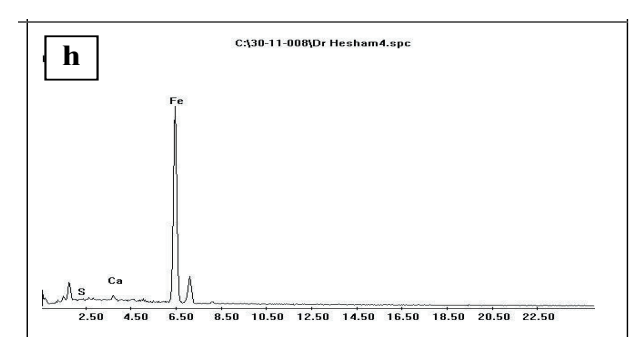

Fig. 6n: ESEM analyses for the studied heavy minerals from Wadi Wassif; h) iron oxide after pyrite

Ilmenite [FeTiO $]$ : is the most abundant $\mathrm{Fe}$-Ti oxide mineral that occurs in a wide variety of igneous rocks, some metamorphic rocks, and as detritus mineral grains. Ilmenite constitutes $0.086 \%$ in the studied stream sediments and occurs as irregular, tabular or massive angular to sunrounded grains. These grains exhibit black to brownish black colors and metallic to submetallic luster. The brownish tint of some ilmenite mineral grains may be due to the partial alteration of these grains.

Garnet: The minerals of garnet group characterize some metamorphic rocks, others occur in some igneous types, and can be noticed generally as detritus grains in sediments. The average content of garnet in the studied stream sediments is $0.314 \%$. It exhibits different colors ranging from pale pink to dark brown with vitreous luster. Sometimes, garnet grains appear to be cloudy due to staining or inclusions. The alamandine type is the common garnet mineral in the studied samples.

\section{DISTRIBUTION OF U AND Th}

The examined stream sediments of Wadi Wassif are characterized by radiometrically low concentrations of $U$ and Th (Table 6). The radiometrically elemental concentration of $U$ range between 1 and $4 \mathrm{ppm}$ with an average $2.9 \mathrm{ppm}$, while it is between 8 and 28ppm for Th with an average $17 \mathrm{ppm}$. The average Ra content for these sediments is $2.8 \mathrm{ppm}$, ranging between 1 and 4ppm. 
Table 6: eU, eTh, Ra (ppm) and K (\%) content, and some elemental ratios of the stream sediments of Wadi Wassif

\begin{tabular}{|c|c|c|c|c|c|c|}
\hline $\begin{array}{c}\text { Sample } \\
\text { No }\end{array}$ & $\begin{array}{c}\mathbf{e U} \\
\text { (ppm) }\end{array}$ & $\begin{array}{c}\text { eTh } \\
\text { (ppm) }\end{array}$ & $\begin{array}{c}\text { Ra } \\
\text { (ppm) }\end{array}$ & $\mathbf{K}(\%)$ & eTh/eU & $\begin{array}{c}\text { ARs } \\
(\mathbf{e U} / \mathbf{R a} \mathbf{a})\end{array}$ \\
\hline WS1 & 2 & 10 & 1 & 1.48 & 5 & 2 \\
\hline WS2 & 1 & 8 & 2 & 1.56 & 8 & 0.5 \\
\hline WS3 & 3 & 20 & 3 & 1.12 & 6.66 & 1 \\
\hline WS4 & 4 & 12 & 2 & 1.05 & 3 & 2 \\
\hline WS5 & 4 & 11 & 3 & 1.07 & 2.75 & 1.33 \\
\hline WS6 & 2 & 24 & 4 & 1.01 & 12 & 0.5 \\
\hline WS7 & 3 & 28 & 4 & 1.18 & 9.33 & 1 \\
\hline WS8 & 4 & 23 & 4 & 0.92 & 5.75 & 0.75 \\
\hline WS9 & 2 & 11 & 3 & 1.04 & 5.15 & 0.66 \\
\hline WS10 & 4 & 15 & 3 & 1.27 & 3.75 & 1.33 \\
\hline WS11 & 3 & 18 & 2 & 0.92 & 6 & 1.5 \\
\hline Min & 1 & 8 & 1 & 0.92 & 2.75 & 0.5 \\
\hline Max & 4 & 28 & 4 & 1.56 & 12 & 2 \\
\hline Av. & 2.9 & 16 & 3 & 1.15 & 6.13 & 1.14 \\
\hline
\end{tabular}

Ivanovich (1994) concluded that a relatively constant $\mathrm{Th} / \mathrm{U}$ mass ratio of around 3.5 is found in most natural systems. The average of the corresponding value (eTh/eU ratio) for the sediments of Wadi Wassif is 6.13varying between 2.75 and 12 which indicate that there is a significant fractionation during weathering of these sediments causing the depletion of $U$.

The main factors controlling the distribution of radioelements in sediments are the geomorphological features of the basin of deposition, radioelements content of the source rocks, grain size of these sediments, the alkalinity of the surface groundwater, and to a lesser extent effect of the organic matter. ${ }^{238} \mathrm{U} /$ ${ }^{226} \mathrm{Ra}$ activity ratios (ARs) can be used to ascertain equilibrium within the same decay series (Navas et al., 2002). If secular equilibrium prevails in the ${ }^{238} \mathrm{U}$ chain, ARs of ${ }^{238} \mathrm{U} /{ }^{226} \mathrm{U}$ will be approximately 1 , ARs values other than 1 indicate disequilibrium. The ARs for the studied stream sediments of Wadi Wasif alternate lower and higher than 1 , which indicate a state of disequilibrium in these sediments.

\section{CONCLUSIONS}

Wadi Wassif area is located in the CED and covering an area of about $48 \mathrm{Km}^{2}$. The rock assemblages cropping out at Wadi Was- sif area are; from the oldest to youngest, metavlcanics, older granitoids, Hammamat sediments, younger granites, and Quaternary alluvial sediments. The qualitative and quantitative mineralogical studies of the stream sediments of Wadi Wassif indicate that these rock assemblages contribute minerals association in these sediments The average heavy minerals concentrations of the stream sediments of Wadi Wassif is $5.56 \%$ that increase from upstream to downstream of the wadi. The concerned heavy minerals and their concentrations include thorite $0.058 \%$, titanite $0.097 \%$, monazite $0.074 \%$, and zircon $0.347 \%$. The associated heavy minerals are garnet, rutile, epidot in addition to opaque minerals that include magnetite, ilmenite and hematite. The stream sediments of Wadi Wassif are characterized by low concentrations of $\mathrm{U}$ and $\mathrm{Th}$. These sediments show a state of disequilibrium and depletion of $U$ due to weathering processes affecting these sediments.

\section{REFERENCES}

Bea, F.,1996. Residence of REE, Y, Th and U in granites and crustal protolith; implications for the chemistry of crustal melt. J. Petrol., 37, 521-552. 
Bea, F., Pereira, M. D., Corretage, L. G. and Fershtater, G. B., 1994. Differentiation of strongly peraluminous, perphosphorous granites: the Pedrobenards pluton, Central Spain. Geochem. Cosmo. Acta, 58, 2609-2627.

Berry, L. G., Mason, B. and Deitrich, R. V.,1983. Mineralogy. Freeman, San Francisco.

El Gaby, S. and Habib, M. S.,1982. Geology of the area south-west of port Safaga with special emphasis on the granitic rocks, Eastern Desert, Egypt. Ann. Geol. Surv. Egypt, 12, 47-71.

El Ramly, M. F. and Akaad, M. K.,1960. The basement complex in the Central Eastern Desert of Egypt, between latitudes 2430 and $2540 \mathrm{~N}$. Geol. Surv. Egypt. Cairo, 8, 35p.

Ewing, R. C. and Haaker, R. F., 1980. The metamict state: Implications for radiation damage in crystalline waste forms. Nuclear and Chemical Waste Management, I, 51-57.

Heinrich, E. Wm.,1958. Mineralogy and geology of radioactive raw materials. McGraw-Hell Book Company, Inc., 653p.

Hinton, R. W. and Paterson, B. A., 1994. Crystallization history of granitic magma: evidences from trace elements zoning. Mineral. Mag., 58A, 416-417.

Ivanovich, M.,1994. Uranium series disequilibrium: concept and applications. Radiochem. Acta, 64, 81-94.
Karavtchenko, G. T.,1960. Colouration of monazite. Akad. Nauk. USSR, Sibir., Octdec. No. 7, 80-90.

Lyakhvich, V. V. and Vishnevskiy, A. A.,1990. Zr and $\mathrm{Hf}$ in rapakivi zircons and the origin of avoids. Geokhimiya., 8, 1075-1083.

Navas, A., Soto, J. and Machin, J.,2002. 238U, 226Ra, $210 \mathrm{~Pb}, 232 \mathrm{Th}$ and $40 \mathrm{~K}$ activities in soil profiles of the Flysch sector (Central Spanish Pyrenees). App. Radiation and Isotopes, 57, 579-589.

Pabst, A.,1952. The metamict state. Am. Mineral., 37, 137-157.

Palache, C., Berman, H. and Frondel, C.,1944. Dana's system of mineralogy. 1,(7th Edition). Wiley, New York.

Speer, J. A.,1980. Zircon. In: Ribble, P.H. (2nd Ed.), Reviews in Mineralogy, 5: Orthosilicate Mineral Soc. Am., Washington D. C., 67-112.

Stern, R. J.,1981. Petrogensis and tectonic setting of late Precambrian ensimatic volcanic rocks, Central Eastern Desert of Egypt. Pre. Res.,16, 195-230.

Wenk, H. R. and Bulakh, A.,2004. Minerals; their constitutions and origin. The Press Syndicate of The University of Cambridge. 


\section{جيولوجية منطقة وادى صيف , وسط الصحراء الثرقية مصر, مع التركيز على الدراسات المعدنية لرواسب الوديان}

$$
\text { اشرف العزب ابر اهيم سليمان ،هشام النحاس و على احمد عمران }
$$

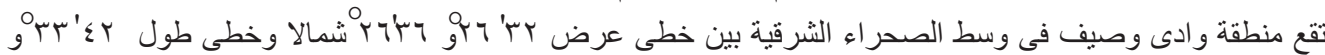

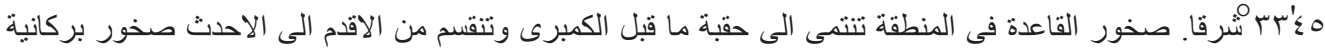
متحولة وصخور جر انيت قديمة (تونالايت) وصخور الحمامات الرسوبية وصخور الجرانيت الحديث (الجرانيت القلوى) ورواسب الوديان الحديثة.

تم در اسة هذه الصخور تحت الميكروسكوب وبدر اسة العينات التى اخذت من المنطقة لتحديد المعادن الثقيلة ومعرفة نسبة

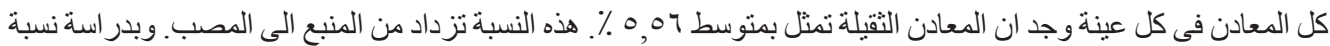

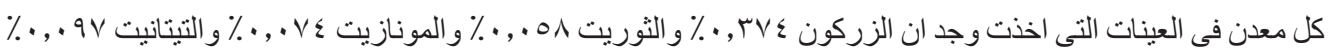
و الروتيل ^ץ • , • ٪ ومعادن اخرى مثل ابيدوت وجارنت وماجنيتيت و المينيت و هيملتيت.

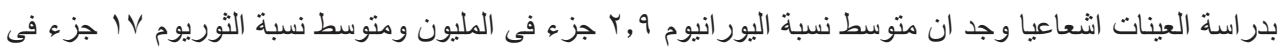

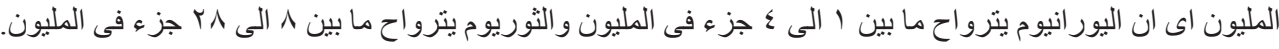

